\title{
REGULATING PLASTICS WASTE, STAKEHOLDER ENGAGEMENT AND SUSTAINABILITY CHALLENGES IN SOUTH AFRICA
}

\author{
Godwell Nhamo
}

\begin{abstract}
In May 2003, the South African government enacted regulations banning the production of thin-film plastic shopping bags. The government advocated that such thin-film plastic shopping bags were indiscriminately discarded because they had no economic and recycling value. However, in as much as the regulations led to significant reductions in plastic shopping bags in the environment, the law resulted in severe unintended negative consequences, as jobs were lost with some businesses in the plastic shopping bag manufacturing sector closing down. The paper also reveals that key stakeholders, such as industry, business and labour, lobbied against the introduction of the regulations but without success. On average, business went down by about $83 \%$ with a conservative $25 \%$ reduction in employment. Drawing insights from the Irish and Australian experiences, this paper critically reviews sustainability debates and responses surrounding environmental regulation and business, with a special focus on the Plastic Bag Regulations in South Africa. Lessons learnt are presented with the intention to provide insights for future waste product or other environmental regulation initiatives in South Africa and elsewhere in the region.
\end{abstract}

Keywords: Environmental regulation. Stakeholders. Plastics. Waste management

\section{Introduction}

Issues pertaining to plastics and the environment are twofold: those around raw materials and production processes and those regarding plastic litter and waste. Plastic usage has increased remarkably in the last decade, and this has led to pressure on the source of raw materials (Stevens 2002). Virtually, all plastics are made from non-renewable, heavy pollutant petroleum products (crude oil, natural gas and coal). On the other hand, the problem of plastic waste, both in the managed mainstream 
and litter is not new. In the 1960s, it was suggested that so much plastic had been produced that the entire planet 'could be wrapped in it' (Stevens 2002: 6), and it is not so much the use of plastic that poses the greatest threat but the magnitude of its use. An estimated 30 billion kilograms plus of plastics are generated annually in the USA alone (Levy 2000). Of this figure, more than $50 \%$ becomes part of the municipal solid waste stream of which plastic in this waste stream account for between $5 \%$ and $7 \%$ of the total weight (Fishbein 1994). Overall, more than $50 \%$ of all discarded plastic comes from packaging, of which a third is accounted for by one- way packaging such as shopping bags. Plastic litter, particularly plastic bags, is also associated with severe aesthetic poverty. Highways and other environs are littered, with beach litter often containing between $40 \%$ and $60 \%$ plastics (Hugo 2004). Plastic litter is also hazardous to a range of living creatures that can die as a result of ingestion or by becoming entangled. It is estimated that more than 100,000 marine mammals and 700,000 sea birds (Short 2003) die every year from encounters with plastic marine debris.

About 3,500 particles of plastic per square kilometre of sea were recorded off the southern coast of South Africa, and other surveys conducted in the Eastern Cape to Cape Town showed plastic waste increasing by about $90 \%$ since 1999 (Hugo 2004). The problem is widely spread to the extent that plastic litter and waste is found even on remote rural beaches. Plastic waste found on urban beaches is mainly land-based, originating from packaging, while that on rural beaches originates from ships such as those involved in the fishing industry (Gjerde and Kelleher 2004). On average, plastic comprises about 7\% (by total weight) of urban waste in South Africa (Hugo 2004). Some of the negative impacts of plastic litter and waste recorded in the country include unsightly landscapes, killing of marine life, increased waste management costs through clean-up operations, clogging of storm-water drains resulting in flooding and persistence and accumulation in the environment. An estimated R8 million (US\$/ZAR exchange rate averaged 1:6 in January 2005) is budgeted annually for clean-up operations by local authorities, and the cost of the deterring impact of plastic debris to tourism is 
probably many more millions. The major challenges to governments therefore are to come up with appropriate regulatory frameworks to deal with the problems associated with plastic shopping bags litter and waste.

\section{Regulating Plastic Bags Waste: International Perspective}

There are a number of approaches that have been instituted to address the plastic shopping bags litter and waste internationally. The packaging waste management policy instruments range from self-regulation through economic to command and control. Ireland, for example, pioneered the plastic shopping bag levy paid directly by consumers at the point of purchase in 2001 (Department of Environment and Local Government 2004). In 2002, Australia drafted two bills (Environment Protection and Heritage Council 2002) focused on regulating plastic shopping bags. Efforts were also made to review a dual management system of plastic and other packaging wastes based on the Packaging Covenant (a self-regulation measure from industry and business) and the government directed National Environmental Protection (Used Packaging Materials) Measure both instituted in 1999 (National Environment Protection Council 1999). Other countries that have regulated or are in the process of regulating against plastic shopping bags waste include New Zealand, Jordan, China, Singapore, the UK, Taiwan, India, Hong Kong and Canada (Zero Waste New Zealand Trust 2003). In Africa, such countries include Botswana, Kenya, Lesotho and Namibia. For the purposes of this paper, the Irish and Australian experiences will be reviewed to provide analytical lenses to the South African experience.

\section{The Irish Experience}

A consultant report on issues surrounding shopping plastic bag litter recommended a levy of between 4.5 and 15 Euro cents (Department of Environment and Local Government 1998). Although the report recommended that the supermarkets or suppliers of plastic shopping bags pay this levy, the Minister of Environment and Local Government decided that the shopper should pay. A study conducted to determine public opinion on the levy revealed a unanimous support for the initiative. Waste 
law reforms were instituted before the implementation of the legislation, and this included putting in place a central reference document entitled $\mathrm{A}$ Policy Statement on Waste Management: Changing Our Ways in 1998 and the amendment of the 1996 Waste Management Act in 2001 to include provisions for a levy on plastic shopping bags and the establishment of an Environment Fund (Department of Environment and Local Government 2001). Other policy reforms included the introduction of the landfill levy. The Irish experience is a direct response to the requirements of the European Union Directives on Packaging and Packaging Waste of 1994 and that on Landfill of 1999 (Department of Environment and Local Government 2004).

Of critical importance to note is the manner in which public awareness was raised. Before the implementation of the Plastic Shopping Bag Levy on 4 March 2002, a TV public awareness campaign was instituted starting 11 February on all Irish TV stations and was to run for a full month. This was complemented by the distribution of indoor posters and information leaflets to all retailers so as to help them in providing information on the levy to the customers. The leaflets were made available through the local authorities and the Department of Environment and Local Government. Revenue Commissioners who were to be responsible for the collection of the levy from retailers issued separate information to retailers regarding their obligations. Local authorities with the help of the Environment Protection Agency monitor non-compliance. According to the Regulations, noncompliance attracts a fine of up to 1,905 Euro or imprisonment of up to 1 year or both or, on conviction and indictment, imprisonment of up to 10 years. 
Within the first 4 months, over a billion plastic bags (90-95\% less of prior consumption) had been removed from circulation. The Revenue Commissioners reported total earnings of 3.5 million euro from about 3,000 retail outlets countrywide. A year after the introduction of the levy, about 9.6 million euro had been generated for the Environment Fund. The trend is reported to be continuing steadily with a $90 \%$ reduction in total consumption prevailing (Department of Environment and Local Government 2004). Already, local authorities have started benefiting from the Environment Fund with budgets allocated for the enforcement of the waste laws. In 2003, the Irish Government put in place a comprehensive packaging waste regulation that forces major producers to take back their packaging waste directly or join a national collection scheme run by Repak Ltd (Department of Environment and Local Government 2003).

\section{The Australian Experience}

As already indicated, central to Australia's policies aimed at 'taking back' packaging waste are the Packaging Covenant and the Government initiated National Environment Protection (Used Packaging Materials) Measure. However, following disagreements over the selection of policy instruments during the period when the Plastic Bags (Minimisation of Usage) Education Fund and the Plastic Bags Levy (Assessment and Collection) Bills (Australian Retailers Association 2003) were formulated, the Minister for Environment Protection and Heritage established the National Plastic Bag Working Group. The group, which fell under the National Packaging Council, was given mandate to investigate workable approaches in reducing environmental impacts of plastic shopping bags litter. The Working Group was made up of representatives from major stakeholders like Environment Australia, Local Government, National Packaging Covenant Council, Plastics and Chemicals Industries Association, Woolworths Ltd, Council for the Environment of Philanthropy in Australia, EcoRecycle Victoria,

Planet Ark Foundation Ltd, Victorian Environment Protection Authority, Australian Retailers Association, Coles Myer Ltd, Clean Up Australia, Packaging Council, NSW Environment Protection Authority, Paperlin Ltd, 
Australian Consumer Association and Amcor. The composition of the Working Group gives good insight into stakeholder participation in policy matters.

Since December 2002, the Australian government has set a target to cut by half the use of plastic shopping bags by December 2004 and sustainably increase the rate of recycling. It called for a $90 \%$ participation rate from major retail chains and a $25 \%$ participation rate from small retailers through the voluntary National Code for the Management of Plastic Retail Carry Bags of 2003. Other stakeholders fully involved during the policy formulation and implementation process included the National Packaging Covenant Council that provided specific proposals for national action, including ways of reducing the impact of plastic bags as litter. Furthermore, a report on The Impacts of Degradable Plastic Bags in Australia was also produced to explore potential in this area. Australians produced about 6.9 billion shopping plastic bags amounting to an estimated 326 bags per person annually (Zero Waste New Zealand Trust 2003).

The Bio Bag has also been developed by Amcor Flexibles Australasia. Utilising the catalyst chemistry of Environmental Plastics Incorporated, it is said to be Australia's first fully degradable plastic bag based on Totally Degradable Plastic Additives technology. Compostable bags are designed to degrade in a composting window of 2 to 4 months where temperature is above $60^{\circ} \mathrm{C}$ with a moisture content of $55 \%$. Landfill bags are designed to degrade, when buried underground, within 2 to 3 years where temperature is around $35^{\circ} \mathrm{C}$.

The Australian experience after 5 years of implementing the Packaging Covenant has been a qualified success. The local authorities have complained of their marginal involvement (Australian Retailers Association 2003). Local governments allege that the proceedings around the plastic shopping bags regulations and other packaging 
waste management initiatives are dominated by industry and business. Hence, both the Packaging Covenant and the National Environmental Protection (Used Packaging Materials) Measure's life spans have been extended to the end of 2004 to allow further consultations on the way forward.

\section{Methodology}

Data for this paper were generated mainly through document analysis (Creswell 2003), interviews (Arksey and Knight 1999) and observation (Silverman 2001). The documents included those used for policy discussion, consultancy reports, white papers, policies, government memoranda, acts, emails, media articles, press releases, letters and submissions. Also included were records in the form of meeting minutes and official press statements from the Department of Environ- mental Affairs and Tourism, retail chain group Pick'n Pay, Plastics Federation of south Africa and other key stakeholders. Creswell (2003: 187) highlights a number of advantages associated with using data from documents, among them the fact that they enable:

A researcher to obtain the language and words of participants, can be accessed at a time convenient to the researcher - an unobtrusive source of information, represents data that are thoughtful, in that participants have given attention to compiling them and as written evidence, it saves the researcher the time and expense of transcribing.

Validation through document analysis took place as data from these sources provided explanations as to why new findings either differed or supported the existing theories and/ or literature. Validity threats (Maxwell 1996) associated with ethics in interviewing were also addressed. As such, issues of informed consent, privacy, confidentiality, anonymity, accuracy and data security had to be addressed appropriately. Interviews were coded as follows: Interview FF1-24 (for face-to-face interview numbers 1 to 24) and Interview T1-31 (for telephone interview numbers 1 to 24). E-mails were also 
coded likewise as E-mail 1-15 for e-mail numbers 1 to 15 . However, it should be noted that, as an output of a bigger study, some of the interviews and emails are not cited in this publication. Observations were also done (Silverman 2001) with permission to access selected major retail outlets to monitor plastic bags consumption from the tills having been granted in Grahamstown (Eastern Cape Province).

\section{Presentation of Research Findings}

Findings from this paper are presented in five sections that include: (1) events leading to the promulgation of the Plastic Bag Regulations, (2) emerging sustainability debates, (3) retailers' perspectives on the May 2002 regulations, (4) organized business' alternative proposal to the Plastic Bag Regulations and (5) the environment/socio-economic interface in relation to the regulations. These sections will now be presented each in turn below. Promulgation of the Plastic Bag Regulations

Based on Section 24 (1) (a) and (k) of the Environment Conservation Act of 1989, the Minister of Environmental Affairs and Tourism, through the Department of Environmental Affairs and Tourism (DEAT) promulgated the Plastic Bag Regulations and gazette them for public comment on 19 May 2000 (Republic of South Africa, hereafter, RSA 2000). The draft regulations proposed to prohibit the manufacture of plastic shopping bags of less than 30 $\mu \mathrm{m}$ in thickness by the first of January 2001 and $80 \mu \mathrm{m}$ wall thicknesses respectively by the first of June 2001. Any person who contravened the provisions of the regulations would be guilty of an offence and liable, on a first conviction, to a fine not exceeding R10, 000 or imprisonment for a period not exceeding 1 year or to both. In the case of a second or subsequent conviction, the offender would be liable to a fine not exceeding R100, 000 or to imprisonment not exceeding 10 years or to both. 
An explanatory memorandum to the regulations had this to say concerning the problems associated with the plastic shopping bags (RSA 2000: 2):

The collection and disposal of plastic bags is a growing problem in South Africa. The use of plastic bags made of thin plastic film has increased significantly in recent years and the discarding of large numbers of bags has resulted in pollution and degradation of the environment. Thin nonreusable bags are indiscriminately dumped and not collected for recycling or disposal.... The problem is severe in low-income areas where waste collection services are inadequate.

\section{Emerging Sustainability Debates}

The proposed regulations did not go down well with, especially industry and business, which thought the regulations, would lead to lost business, capital investment and jobs. This resulted in a consortium submission that involved five organizations led by the umbrella body for the plastics industry in South Africa, the Plastics Federations of South Africa (PFSA). The other organizations that were enrolled in the consortium were the Chemical and Allied Industries Association, South African Chamber of Business, South African Retailers' Association and the Steel Engineering Industries Federation of South Africa. Individual companies and businesses, local authorities, nongovernmental organizations and the general public also made other submissions. Altogether, 99 submissions were presented to DEAT (National Economic Development Labour Council, hereafter, NEDLAC 2001). This resembles a trend similar to the Australian experience highlighted earlier.

The consortium's submission, which also drew insights from the 2000 national survey on Plastic Recycling in South Africa undertaken by the PFSA, raised a number of issues. The submission indicated that public education and awareness rising were the most important and critical aspects in addressing environmental problems related to plastic shopping bags litter and waste in South Africa (Botha 2000). Efforts that were being made by the plastics industry to address the problem associated with plastic shopping bags since the early 1980s were highlighted. The 
Plastics Enviromark was indicated as one of the most successful initiatives. The Plastics Enviromark was started in January 1997 and incorporated the exclusive use of a logo by raw material suppliers and plastics converters who contract to support environmental education and awareness programmes (Plastics Federation of South Africa, hereafter, PFSA 2001). The companies subscribing to the Plastics Enviro- mark are able to express their commitment to environmental responsibility by the use of the logo on their stationery and products. The submission reported that as of October 2000 , about $80 \%$ of the companies in the plastics packaging industry were contributing to the Plastics Enviromark initiative. Some of the awareness programmes covered by the Plastics Enviromark initiative (Botha 2000) include:

- Encouraging manufacturers to use an internationally accepted system to identify the polymer with which a plastic product is made from, so as to facilitate recycling,

- A series of publications aimed at schools and other environmental organizations for community and school use,

- A series of environmental programmes for broadcast on South African Broadcasting Corporation TV and use in schools,

- Financial assistance for educational and environmental bodies, which have been done in some instances in partnership with the Department of Education and Training,

- Major sponsor of Keep South Africa Beautiful for two-and-a-half years, during which it was estimated that some 250,000 school children were reached, and

- Promotion of the Green Cage project that encourages recycling of plastic products through conveniently locating Green Cages around the country. At the time of submission, there were about 120 Green Cages placed in the Eastern Cape, Western Cape, Gauteng, KwaZuluNatal, Free State and Mpumalanga Provinces. 
The submission reported that since the launch of the Green Cage project, more than 70 new job opportunities had been created and that the number of plastic items collected by means of these cages was increasing significantly each month. The consortium also warned that it would be difficult to enforce the proposed regulations and that the issue of imported plastic bags and packaging material were not addressed fully.

Although the consortium submission admitted that there was a need to address the problem of plastic shopping bags litter and waste, it hinted at their good uses too. It claimed that plastics were vital packaging materials globally and assisted in promoting good environmental stewardship. In South Africa, plastic shopping bags were used in almost every retail outlet as carriers for the customer's purchases and were convenient and cost-effective (Plastic Confederation of South Africa, hereafter, PCSA 2002). Plastic shopping bags were also deemed more environmentally friendly than other alternative materials such as paper bags, the submission emphasized. In conclusion, the submission called for an holistic approach to the litter problem, including a range of actions rather than implementing a prescription on the quality of plastic shopping bags only. The submission also warned that at least 3,800 jobs could be lost as most companies would be forced to close down as most modern equipment could not produce plastic shopping bags of up to $80-\mu \mathrm{m}$ wall thickness. This is a position that was carried throughout the lobbying period by the industry even during the public hearing and until 2002 when the regulations were first finalized (PFSA et al. 2002).

After the public submissions, the Environmental Affairs and Tourism Parliamentary Portfolio Committee held a Public Hearing on Plastic Bag Regulations of 27 October 2000 (Parliamentary Monitoring Group 2000). During the hearing, representations were made both for and against the proposed law from the plastic shopping bag producers, PFSA and retailers (who all were against) and the NCOs, individuals and government (represented by DEAT) who supported the regulations. Those against the regulations presented similar sentiments as those that were raised by the consortium submission. 
During its submission, DEAT indicated that plastic shopping bags were being regulated because they were most visible pollutant in the environment. However, reacting to the presentations by industry and their associate partners, the DEAT Director-General (DG) accused the industry of not giving the Portfolio Committee and the public correct information about the job implications of the proposed regulations. The DG claimed that the industry had failed to mention the possibility and probability of job creation in the alternative carry facility proposed product industries. The DC also claimed that DEAT had found that the demand for plastic shopping bags was static. Hence, a shift to alternative carry products was unlikely to decrease the demand for plastic shopping bags. The DC highlighted that DEAT had found that alternative carry products were more labour intensive, leading to more, not less jobs, in the carrying bag industry. DEAT noted that it was mindful that there was a lot of investment in machinery in the industry and asked the industry for information on the current life span of the plants in use, as it could have an effect on the length of the phasing-in period for the proposed regulations. Lastly, the DG emphasized that DEAT was disappointed that the industry had not come up with a viable alternative to the regulations (Parliamentary Monitoring Group 2000).

After the hearing, the DC for DEAT summarized issues emerging from the proceeding and noted that industry wanted a 12-month grace period to come up with a thorough proposal. He indicated that DEAT was, however, concerned as to whether it was being offered a window dressing to prevent the promulgation of the regulations for private interests or the fact that the concerns were genuine. 
The Chair to the Portfolio Committee, however, concurred with the industry that there were problems with the proposed regulations and that they could not be passed without further analysis. The Chair also challenged industry to come up with a solid commitment that could be presented to the Minister (Parliamentary Monitoring Group 2000). After the proceedings, the Committee declared a deadlock and referred the proposed regulations to the National Economic Development and Labour Council (NEDLAC). NEDLAC is South Africa's national organization that discusses and tries to reach consensus between government, organized labour, organized industry and organized communities on issues affecting social and economic policy through social dialogue.

The draft regulations and the comments from the public were tabled by NEDLAC for discussion on 23 November 2000 (NEDLAC 2001), and interested parties, particularly government, organized business and organized labour agreed that a joint research project be urgently undertaken. The scope was that this would assist parties to develop a shared understanding of the potential socio-economic impacts of the proposed regulations. The research would investigate likely impacts on investment, employment and distortionary effects of isolating one aspect of the packaging industry for regulation. The research focused on six major areas that included (NEDLAC 2001):

- Employment, including both direct and indirect job losses,

- Manufacture of plastic shopping bags,

- Potential for alternatives and their manufacture,

- Life cycle analysis of 17/18, 30 and $80 \mu \mathrm{m}$ plastic bags, paper and cloth bags,

- Potential use of biodegradable or photodegradable plastic bags, and

- Distortions that may arise in the markets. 
Data were generated through a questionnaire and interviews with companies (Table 1). Further information was generated from workers' representatives of plastic bag manufacturing companies, DEAT and the Department of Trade and Industry. The NEDLAC report revealed that companies in the plastic bags industry range from very small operations with turnover of less than R5 million per annum, and employing less than 15 people, to large companies with annual turnovers in excess of R200 million, and employing up to 500 people (NEDLAC 2001). The total value of the industry was estimated at R550 million per annum. The plastic shopping bag manufacturing industry was revealed as consisting of six large companies that shared between $70 \%$ and $75 \%$ of the local market, and companies manufacturing plastic shopping bags were almost entirely dependent on that business alone. Small to medium scale companies were found to be using technology that was about 20 years older that that used by large producers. Equipment was found to have a 20 to 30 years life span, with the oldest technology in use having at least 10 years remaining in their life. The machinery used for manufacturing an $80-\mu \mathrm{m}$ plastic shopping bag was deemed different from that required for manufacturing a 30- $\mu \mathrm{m}$ plastic bag. As such, NEDLAC recommended that it was not feasible to change existing equipment to manufacture firstly the required $30-\mu \mathrm{m}$ plastic bag and later an $80-\mu \mathrm{m}$ plastic bag, and no industry was prepared to make such huge capital investment to align with the proposed regulations (NEDLAC 2001).

Table $1 \mathrm{~S}$ a mple for NEDLAC research 2001

\begin{tabular}{lll}
\hline Company & Total identified & Sample realized \\
\hline Polymer producers & 2 & 2 \\
Plastic bag & 42 & 12 (onlv those \\
Recvclers & 85 & 2 \\
& & 2 \\
Pulp producers & 2 & 2 \\
Paper bag manufacturers & 6 & 2 \\
Paper recvclers & 4 & \\
Cloth bag makers & 3 Reping \\
Retail industry & Representative sample & \\
& Of 390 small, \\
& medium and & \\
& large retailers \\
\hline
\end{tabular}


Findings on labour were presented with the main bone of contention being potential loss of thousands of jobs in the industry. NEDLAC established that regulations stipulating $80 \mu \mathrm{m}$ would lead to all local producers closing down. On recycling, the NEDLAC report showed that, although an increase in the thickness of the bag would stimulate recycling, this was likely to offset a maximum of between $10 \%$ and $15 \%$ of production capacity (based on recovery economics) unless other factors constraining recycling in the country were addressed. There was a need therefore to create demand for recycled resins, particularly by specifying a minimum recycle content for refuse and other plastic bags. A life cycle analysis on environmental impacts of plastic shopping bags was done based on a desktop study comparing plastic shopping bags in the USA and a 25-kg distribution sack in Europe. The life cycle studies of the plastic shopping bags indicated that there were less environmental impacts than paper bags in terms of energy consumption, solid waste generation, atmospheric emissions and waterborne wastes (NEDLAC 2001). The study on the $25-\mathrm{kg}$ distribution sack showed that the paper sack had more environmental benefits if compared against primary energy consumption, abiotic resource depletion, global warming, acidification, nutrient enrichment, photochemical ozone formation, aquatic ecotoxicity, air and water emissions. However, conclusions could not be drawn, as these were not comparable to South Africa. As such, NEDLAC recommended that a detailed life cycle analysis be done specifically for South Africa. This was not taken further.

Cloth bags were not common in the country, apart from about 150,000 that were manufactured as a niche product for one large retail chain. The cost of a cloth bag as a substitute to the plastic shopping bag would be about R7. NEDLAC concluded that the option was too expensive although believed to be more durable, and hence, it was not one of the preferred options. As for degradable plastic shopping bags, NEDLAC noted that the technology was still in its infancy stages internationally. Biodegradability, as a terminology, had only surfaced firmly around 1997. The research noted that, with the level of technology in the South African polymer industry, it was not possible to manufacture degradable plastic bags within the short to medium term horizon, although very small scale trials of degradable bags were found (NEDLAC 2001).

After NEDLAC's report and 2 years of negotiations that were now pitching organized labour and organized business against the government, the draft Regulations were passed into law with minor amendments as they appeared in the Government Gazette of 9 May 2002 (RSA 2002). The wall thickness provisions on offences and penalties remained the same as those covered under the May 2000 regulations. This final version of the regulations, which would have entered into force on 8 May 2003 was rejected once more by organized business and organized labour. As such, organized business and organized labour sought further dialogue with the Minister of Environmental Affairs and Tourism, including lobbying the Minister of Trade and Industry to intervene on their behalf. This resulted in ongoing tripartite negotiations between these concerned stakeholders. Organized business was now represented by the Chemical and Allied Industries Association, PFSA, Plastics Recyclers Employers' Organization and the Retailers Plastic Bag Working Group [represented by retail chains Pick 'n Pay (Pty) Ltd, Woolworth (Pty) 
Ltd, Clicks Stores and Shoprite-Checkers (Pty) Ltd]. The Congress of South African Trade Unions (Cosatu), whose individual membership was about 2 million in January 2005, and the National Council of Trade Unions (whose membership was about 5,000 in January 2005) represented organised labour. Retailers' Perspectives on May 2002 Regulations

Two informal submissions in the form of letters directed to the Minister of Environmental Affairs and Tourism were retrieved, one from Pick'n Pay and the other from Woolworths retail chains. The letters dated 16 and 22 May 2002, respectively, raised issues related to the May 2002 Plastic Bag Regulations.

From the letters, which were both written by the retail chains' chief executives, it was clear that both retail outlets had engaged the Government to push for favourable amendments to the original regulations but with limited success. In their letters, the chief executive officers concluded by requesting continued dialogue with the Government. Part of the remarks from the Pick'n Pay letter read:

We appeal to you for further dialogue in weeks ahead, as we certainly believe that with some significant, but minor, modification to the proposed legislation, that a win-win situation could be created for all, as judging by the public response, the legislation is indeed not a popular one and ultimately, we are there to serve the interests of all of our stakeholders.

\section{And for Woolworths, it portrayed almost the same message and read:}

We do believe, Minister, that further dialogue is required between yourself and ourselves. We equally believe that whilst small gains may be made, still bigger ones could be achieved - to the benefit of all stakeholders. We would therefore appeal to you to not overlook our proposals, but to engage with us to achieve the same objectives together. After all, the very aspect of engagement and consultation is the very cornerstone of our young democracy.

The two paragraphs extracted from the letters raise key issues in terms of environmental regulation and policy making in South Africa. The letters talk of cooperative governance and the need for Government to engage more with the affected parties. The letters also clearly show the preferred future from the retailers, thus, a focus on education and awareness raising plus a nominal charge on the plastic shopping bag. The letter from Pick'n Pay clearly indicated that there were other stakeholders that the Croup served, and these were the general public in the form of its customers. From the letter, the customers had indicated that they were not pleased with the idea of paying for a plastic shopping bag. As for the letter from Woolworths, another policy issue was raised that reminded the Minister of the Government's obligation to facilitate and operate in a democratic manner in debating the Plastic Bags Regulations.

\section{Organised Business' Alternative Proposal}


Organised business felt there were not significant changes to the May 2002 regulation compared to the original 2000 version, and this prompted organized business to come up with an alternative self-regulating plan. The business plan was popularised as the e-Bag Initiative.

The e-Bag Initiative aimed at reducing the number of plastic shopping bags that ended up in the waste stream. A levy was proposed at the point of sale of the plastic bag from the manufacturer to the retailer and the retailer in turn charging consumers for the bag at the point of sale. The retailer would also refund consumers for any bags that are returned to the point of sale. This arrangement was confirmed as having the impact to reduce the number of plastic shopping bags in circulation with the levy being used to stimulate the collection and recycling of plastic shopping bags. Industry would increase the thickness of plastic shopping bags to a minimum of $22 \mu$ through regulation and further enhance the recycling content by developing a standard that would specify the characteristics of both shopping and refuse plastic bags. Such a standard would include specifying a minimum thickness, ink to be used and its spread on the plastic shopping bag surface, the area of the bag that may be printed on and optimum size of bags.

The e-Bag Initiative resulted in the Plastic Bag Agreement of September 2002. The Agreement was entered into by government and organised labour as discussed earlier. The government and its social partners adopted the organised business e-Bag proposal and agreed upon several issues including that (DEAT 2002): (1) plastic shopping bags of $30 \mu \mathrm{m}$, with a 20\% tolerance be produced until 9 May 2008, (2) customers be made aware of the cost associated with the new plastic bags before purchase and that retailers were to reduce commodity prices accordingly, (3) a mandatory levy be charged for plastic bags, (5) the May 2002 regulations be repealed and the new set of regulations be enforcement starting 9 May 2003, (6) local producers and retailers promote the Proudly South African initiative that would ensure that local products are given preference so as to create employment and that (7) industry promote the creation of new jobs. In respect of the last point, manufacturers, recyclers and retailers committed themselves not to retrench workers up until 9 May 2008. In addition, a non-profit company was to be established, and it was envisaged that between 180 and 220 direct permanent jobs and between 2,000 and 4,000 more jobs would be created through the extension of recycling.

The Plastic Bag Agreement formalised the rejection of the May 2002 Plastic Bag Regulations and these were repealed when the new-look Plastic Carry Bags and Plastic Flat Bags Regulations were passed into law in the gazette of 9 May 2003 (RSA 2003). This is the same day the new regulations entered into force. There were two noticeable revisions in the new regulations: specification of wall thickness and fines against offenders. The wall thickness was set at $24 \mu \mathrm{m}$ minimum and the R100,000 fine was removed.

\section{The Environment/Socio-Economic Interface}


Although not immediately coming into existence by 9 May 2003 as indicated in the Plastic Bag Agreement, information supplied by the Chief Executive Officer (CEO) of the PFSA through a telephone interview (Interview T31, 2004-09-08) revealed that the non-profit company had only been registered a year later on 26 May 2004. However, the CEO expressed that it was going to take 'a good many, many, many months before the company starts operating (Interview T31, 2004-09-08). This comment was made in light of the confusion that surrounded the manner in which the plastic shopping bag levy was to be forwarded to the company. Part of the confusion and tensions behind the scene revealed that the plastic shopping bag producers were reluctant to release money into National Treasury coffers. This emerged from two interviews granted by representative bodies of the plastics and packaging industry (Interview T15, 2004-02-17; Interview T31, 2004-09-08). One of the respondents indicated that they feared that, once money has been put into Treasury, it could "be anybody's money, including a chance of it being misused by being directed away from the clean up and recycling purposes it is intended for" (Interview T15, 2004-02-17). As such, industry was more comfortable releasing the levy if ring-fenced so that it would be easily re-directed into the company account.

Proceedings surrounding the implementation of the May 2003 Plastic Bags Regulations did not favour labour as well. Following what Cosatu called "a threat of massive job losses in the plastic bag industry", a press statement and notice of intention to strike were issued on 7 August 2003 (E-mail 2, 2003-08-08). The notice of intention to strike was issued on behalf of the Chemical, Energy, Paper, Printing, Wood and Allied Workers' Union, South African Chemical Workers' Union and the South African Commercial, Catering and Allied Workers' Union. Part of the background message to the notice indicated that parties to the Plastic Bag Agreement concurred 'that there was a need to address environmental issues in a sustainable manner The agreement also attempted to ensure that DEAT's regulatory efforts would be optimised whilst minimising any negative social or economic impacts, especially those relating to workers, the poor, women and rural areas' (E-mail 2, 2003-08-08).

The notice went on to mention that an unintended consequence of the agreement was that "demand for plastic bags has plummeted by between $80 \%$ and 90\%' (E-mail 2, 2003-08-08), and this was due to misleading advertising by certain retailers who indicated that it was the law to charge for plastic shopping bags. In a way, Cosatu's notice claims that an agreement was never reached that retailers had to charge for plastic shopping bags in the first place. The claim was that the Plastic Bags Regulations did not enforce charging but thickness and printing. However, Cosatu alleged that DEAT 'pursued companies not signatory to the agreement, trying to enforce charging across the board', among them, Mr Price clothing retail chain.

A bigger issue is raised here regarding the tensions around who should and should not charge for the plastic shopping bags. The conclusion is that only those companies that were signatories to the Plastic Bag 
Agreement were supposed to be charging. Therefore, $40 \%$ of retail outlets in the country represented by Pick'n Pay, Woolworths, Shoprite-Checkers and Clicks Stores were the only ones required to charge for the plastic shopping bags (Department of Environmental Affairs and Tourism, hereafter, DEAT 2002).

Cosatu then demanded that charging for plastic shopping bags end immediately as more jobs were on the line in the production sector. Reference was also made to 'numerous meetings' that had been held with DEAT, the plastic shopping bag manufacturers and the retailers in an attempt to address the problem (E-mail 2, 2003-08-08). However, while all parties acknowledged the problem and indicated their commitment in addressing it, Cosatu did not believe that the substantive positions tabled by the retailers and Government would ensure that jobs were saved. As such Cosatu demanded that:

There be no charge for plastic bags for 6 months from the date of notice,

- After 6 months, market forces were to determine the price for plastic shopping bags and that implied retailers could charge whatever amount they see fit, including no charge at all. After that retailers were free to choose whether they wished to charge separately or to build the cost of the packaging into their overall cost.

- In the interim, the Government, retailers and labour were to work together to

- communicate the reasons for the charge to consumers, and

- That Buyisa-e-Bag had to be established urgently and opportunities for recycling plastic shopping bags made available in or near all major retail outlets.

The fact that there were significant retrenchments is one of the unintended outcomes of the Plastic Bags Regulations. In the first place, the Plastic Bag Agreement indicated that no retrenchment would take place before May 2008, and yet, this took place even before the regulations were implemented on 9 May 2003. Conservative figures supplied by the PFSA in February 2004 indicated that, 3 months after the regulations entered into force, an estimated 500 plus jobs had been lost in the production sector only (Interview T14, 2004-02-16). A follow-up on this issue revealed that up to 1,000 jobs (Email 16, 2004-11-08) had been lost. However, more job losses were likely to be experienced amongst the recyclers and collectors, especially small-scale community-based recycling projects (Interview T14, 2004-02-16).

A follow-up on raw data figures through telephone interviews and e-mails with producers in February 2004 revealed the following facts relating to some of the producers including two of the top three (Table 2) that share a conservative $65-75 \%$ of the market in the country. In fact, one of the companies sampled used to produce about $45.63 \%$ (3.65 billion) of plastic shopping bags annually for the country (E-mail 13, 2004-02-16; Interview T11, 2004-02-16). This is by far the largest single entity in the South Africa plastic shopping bag market.

What emerged from these interviews were sorrowful narratives regarding the social and economic pain 
on the part of the employer and employees (Interview T25, 2004-02-17). Certainly none between them had advocated for the Plastic Bags Regulations, and in their views, the consequences were getting 'to the wrong people' altogether. Concerned with the balance between environmental and social-economic considerations, one of the respondents, an operations manager for company ' $E$ ' in Table 2, reiterated that there were real job losses and "at the end of the day jobs weigh more than the environment" (Interview T25, 2004-02-17). The respondent could not hide the difficulty experienced in balancing the two.

Table 2 Loss of employment as of February 2004

\begin{tabular}{llllll}
\hline Company & $\begin{array}{l}\text { Date } \\
\text { surveyed }\end{array}$ & $\begin{array}{l}\text { Staff complement } \\
\text { before PBR }\end{array}$ & $\begin{array}{l}\text { Staff } \\
\text { complement } \\
\text { after the PBR }\end{array}$ & $\begin{array}{l}\text { Number } \\
\text { retrenched }\end{array}$ & \%etrenchment \\
\hline A & $16-02-04$ & 425 & 209 & 216 & 49.18 \\
B & $16-02-04$ & 27 & 14 & 13 & 48.15 \\
C & $17-02-04$ & 15 & 0 & 15 & 100.00 \\
D & $17-02-04$ & 25 & 10 & 15 & 60.00 \\
E & $17-02-04$ & 150 & 100 & 50 & 33.33 \\
Total/Average & - & 642 & 333 & - & 58.13 \\
\hline
\end{tabular}

I should say my reaction is split. On one hand it pained me to retrench some of our workers who had served the company for more than 20 years. However, on the other side, I am a nature person and the regulations are doing well to clean up the environment. You see. Really it is a catch 22 situation.

Only 1 of the 24 surveyed companies indicated that they had not been impacted negatively by the new law (Interview T16, 2004-02-17). The reason given by this company was that it only started dealing with plastic shopping bags after the new law had already entered into force. As such all the investments and employment were relative to the market dictates. The other aspect that came out clearly from the recyclers sampled was that they did not recycle the old plastic bags at all, and this was due to the reasons alluded to earlier.

Average figures from one of the major producers revealed that only 1,325 million plastic bags per day (about 311.4 million bags a year compared to 3.65 billion before the regulations) were being produced (E-mail 13, 2004; Interview T11, 2004). This represents an estimated 92\% cut in the actual number of plastic bags getting to the consumers and a $42 \%$ slash of shopping plastic bags consumption and circulation at a national level if the base of 8 billion plastic shopping bags (NEDLAC 2001) circulated annually previously in the county is used.

The demand for plastic bags was also monitored for a complete year in two out of the three major groceries retail chains in Grahamstown between January 2003 and January 2004. The period was selected to provide insights concerning demand before the regulations and demand after the regulations. Three distinctive phases emerged: one focusing on before the regulations (January to 8 May 2003), the other 
when the plastic bags were sold for between 26-46 cents (9 May to 11 August 2004) and when the plastic shopping bag 'war' erupted resulting in plastic bag prices being cut to between 10-17 cents (12 August and after). This is the price that plastic bags are being sold at to-date. Monitoring direct consumption was done to experience the real situation on the ground as events unfolded at the 'lowest' possible scale (local). The figures then presented a good case for comparison with sectoral and national patterns. This meant that, by the end of the day, a more plausible conclusion could be reached concerning short- to medium-term demand trends.

The demand situation from the observations is presented in Fig. 1. The figures presented in Fig. 1 show that demand trends at the local scale were similar to those experienced by the raw materials supplier and producers. The average monthly plastic shopping bag demand drastically fell by $98.8 \%$ (for Retailer A) and 99.1 (for Retailer B) during the first 3 months after the introduction of the Plastic Bags Regulation on 9 May 2003.

However, the demand increased slightly after the reduction in plastic shopping bags prices on 12 August 2003, although overall, the demand remained subdued at $2.4 \%$ of the base average monthly consumption of 500,000 (for Retail A) and $1.8 \%$ (for Retail B) in the next 3 months between August to October. The trend improved slightly as revealed during interviews with the management of the two retail outlets, and this was attributed to normal increase in consumption during the Christmas and New Year festive season (Interview FF10, 2003-05-20; Interview FF9, 2003-05-19). Average monthly demand rose slightly to $2.8 \%$ (from $2.4 \%$ ) of average monthly base consumption of 500,000 (for Retail A) and $2.2 \%$ (from $1.8 \%$ ) for Retail B. 


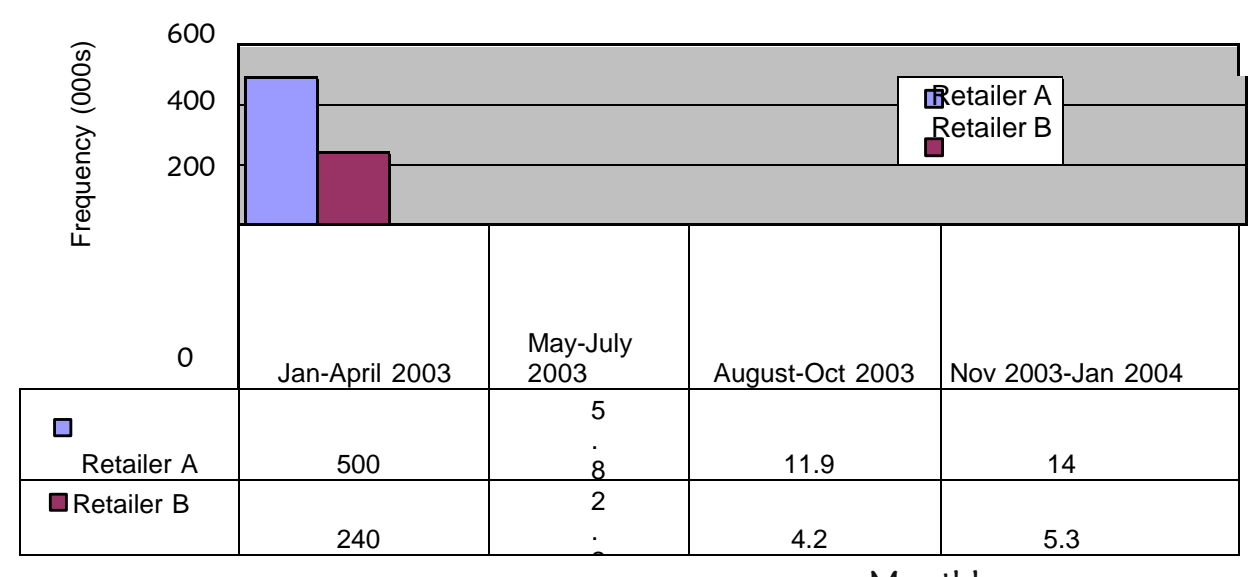

Monthly average

Fig. 1 Retail plastic shopping bags demand

Overall, the monthly average demand for the two retail outlets fell by $98 \%$ from the period when the regulations were enforced to the end of the monitoring period in January 2004. At the national level, plastic shopping bags demand figures reported 3 months after the enforcement of the Plastic Bags Regulations by the PFSA showed reductions that ranged between $75 \%$ and $90 \%$ reduction. From a statement that appeared on the DEAT website on 16 July 2003 (http:// www.environment.gov.za/, 8 August 2003), the Wildlife and Environment Society of South Africa (WESSA) was one of the early beneficiaries of the introduction of the Plastic Bags Regulations. Its joint initiative with the Spar retail chain to introduce the Cloth Bags and EcoBag resulted in two sets of donations: a R16, 000 donations for WESSA Border-Kei Region Office in October 2000 and another R50, 000 on 18 July 2003 for the Head Office in Kwazulu-Natal. Follow-up interviews granted by Makana, Nelson Mandela Metro, City of Cape Town, Govarn Mbeki and Tshwane local authorities also confirmed that the new law has led to a significant reduction in plastic shopping bags litter and pollution in the environment. Given this scenario, one may generally conclude that the regulations have had an impact in terms of the total amount of plastic shopping bags waste getting into the environment. Another environmental benefit has been the Kids in Parks Programme.

The Kids in Parks Programme is an initiative aimed at transforming and developing the school curriculum. The programme was jointly launched by the Ministries of Education and Environmental Affairs and Tourism in partnership with Pick'n Pay and South African National Parks (SANParks) on Tuesday, 26 October 2004 at the West Coast National Park in Langebaan in the Western Cape Province. The environmental education programme aims to (http://www.environment.gov.za/, 25 November 2004): (1) provide meaningful environmental education (within the framework of Outcomes-Based Education and Curriculum 2005) so as to equip future generations with the knowledge and skills needed to manage the environment, (2) enhance cultural resource management and indigenous knowledge, (3) strengthen community-parks relationships and (4) contribute to local economic development through subcontracting, community-driven enterprises, joint ventures, apprenticeships and employment. Pick'n Pay has provided close to R9 million as 
seed money towards the initiative. The donation follows the group's pledge to make R1 available to an environment project from the proceeds of the Green Bag sale. The Green Bags are being sold exclusively by the group in South Africa and across the borders as an 'environmentally friendly' alternative to plastic shopping bags.

In a Parliamentary update on 16 September 2003, the Minister noted that although there were no scientific surveys conducted, the Ministry had received "numerous anecdotal reports from various sectors of society" ranging from farmers who indicated that their cattle were not being choked any longer, to tourists who had informed government about "noticeable decrease in plastic bags in the countryside" (http://www.environment.gov.za/, 30 September 2003).

The following were some of the observed changes highlighted by the Minister since the implementation of the Plastic Bag Agreement:

- There had been a reduction in consumption of plastic bags by consumers since the implementation of the

Plastic Bag Agreement requiring consumers to pay for bags,

- Consumers were increasingly re-using plastic shopping bags when doing their shopping and

- There was a heightened awareness by consumers of the need to reduce pollution and the impact had been that less plastic was being disposed of in manner that is detrimental to the environment supporting the $3 \mathrm{R}$ policy of reducing, re-using and recycling waste.

\section{Conclusion}

This paper presented the debates and responses surrounding environmental regulation and sustainability issues in South Africa. The formulation and implemen- tation processes of the Plastic Bag Regulations were used as an illustrative case. It emerged that although the regulations resulted in a significant reduction in plastic shopping bags getting into South Africa's environment, the major concern was on job losses and related social impacts as well as lost revenue and capital investment, particularly from the plastic shopping bags manufacturing sector. One of the major environmental beneficiaries was identified as the Kids in Parks Programme. Given that the government's preferred future is to regulate waste streams, the paper also presented insights for such initiatives. The case also revealed that the elements of the Irish experience informed developments in South Africa. Similar patterns in the reduction of plastic bags and the environmental law reform around the plastics bags regulations also emerged in the South African case. The powerful (self-regulation) voice of organised industry came out strongly in the case under review, and this resembles the Australian experience in many respects. Overall, sustainability challenges pertaining to environmental policy processes surrounding South Africa's Plastic Bags Regulations remain a landmark on environmental regulation terrain and road map for both the country and the Southern African region at large.

Acknowledgements Authors thank Nampak and Codesria for financial support. 



\section{References}

Arksey, H., \& Knight, P. (1999). Interviewing for social scientists: An introduction with examples. London: Sage.

Australian Retailers Association (2003). Submission to the Senate inquiry into the Plastic Bag Minimization of Usage) Education Fund Bill 2002 and Plastic Bag Levy (Assessment and Collection) Bill 2002. Brisbane: Australian Retailers Association.

Botha, E. (2000). Industry wants more debate on plastic bag problem. Daily Dispatch, September 14.

Creswell, J. W. (2003). Research design: Qualitative, quantitative and mixed methods approaches. Thousand Oaks: Sage.

Department of Environmental Affairs and Tourism (2002). Plastic Bags Agreement. Pretoria: Department of Environmental Affairs and Tourism.

Department of Environment and Local Government (1998). Consultancy study on plastic bags. Dublin: Department of Environment, Heritage and Local Government.

Department of Environment and Local Government (2001). Waste Management (Amendment) Act 2001. Dublin: Department of Environment, Heritage and Local Government.

Department of Environment and Local Government (2003). Waste Management (Packaging) Regulations, 2003. Dublin: Department of Environment, Heritage and Local Government.

Department of Environment and Local Government (2004). Waste Management: Taking stock and moving forward. Dublin: Department of Environment, Heritage and Local Government.

E-mail 2. (2003). Cosatu position on plastic bag regulations. National Economic Development Labour Council, Pretoria, August 8, 2003.

E-mail 13. (2004). Request for information concerning plastic bags production. Nampak Polyfoil, Cape Town, February 16, 2004.

E-mail 16. (2004). Request for information concerning plastic bags production. Nampak Polifoil, Johannesburg, February 16, 2004.

Environment Protection and Heritage Council (2002). Plastic Shopping Bags in Australia. Canberra: Environment Protection and Heritage Council.

Fishbein, B. K. (1994). Germany, garbage and the green dot: Challenging the throwaway society. New York: Inform.

Gjerde, K. M., \& Kelleher, G. (2004). High seas: conservation beyond the fringe. The IUCN Bulletin: Rediscovering Planet Ocean, 1, 4-5.

Hugo, M. L. (2004). Environmental management: An ecological guide to sustainable living in Southern Africa. Ecoplan: Brooklyn Square.

Interview FF 9. (2003). Responses during Plastic Bags Regulations Implementation. Spar, Grahamstown, May 19, 2003.

Interview FF10. (2003). Responses during plastic bags regulations implementation. Checkers, Grahamstown, May 20, 2003. 
Interview T 11. (2004). Impacts of plastic bags regulations implementation. Nampak Polyfoil, Johannesburg, February 16, 2004.

Interview T 14. (2004). Impacts of plastic bags regulations implementation. Plastics Federation of South Africa, Johannesburg, February 16, 2004.

Interview T 15. (2004). Impacts of plastic bags regulations implementation. Packaging Council of South Africa, Johannesburg, February 17, 2004.

Interview T 16. (2004). Impacts of plastic bags regulations implementation. ITB Manufacturing, Durban, February 17, 2004.

Interview T 25. (2004). Impacts of plastic bags regulations implementation. Transpaco, Johannesburg, February 17, 2004.

Interview T 31. (2004). Status of Buyisa-e-Bag Company. Plastics Federation of South Africa, Johannesburg, September 8, 2004.

Levy, G. M. (2000). Packaging, policy and the environment. Paris: Aspen.

Maxwell, J. A. (1996). Qualitative research design: An interpretive approach. London: Sage.

National Economic Development Labour Council (2001). Socio-economic impact of the proposed plastic bag regulations. Johannesburg: National Economic Development Labour Council.

National Environment Protection Council (1999). National environment protection (used packaging materials) measure. Brisbane: National Environment Protection Council.

Parliamentary Monitoring Group (2000). Public hearing on plastic bag regulations. Johannesburg: Parliamentary Monitoring Group.

Packaging Council of South Africa (2002). Dismay at revised regulations, Packaging Review, May 2002, 28, 33.

Plastics Federation of South Africa (2001). Plastics recycling: A survey of the South Africa recycling Industry 2000. Johannesburg: Plastics Federation of South Africa.

Plastics Federation of South Africa, Plastics Recycling Employers Organisation, and Chemical and Allied Industries Association (2002). Towards eliminating plastic bags from the environment: A plastics industry initiative. Johannesburg: Plastics Federation of South Africa, Plastics Recycling Employers Organization, and Chemical and Allied Industries Association.

Republic of South Africa (2000). Proposed regulations under Section 24 of the Environmental Conservation Act, 1989 (Act N0. 73 of 1989). Cape Town: Government Printer.

Republic of South Africa (2002). Plastics bags regulations. Cape Town: Government Printer.

Republic of South Africa (2003). Regulations for the plastic carrier bags and plastic flat bags. Cape Town: Government Printer.

Short, M. K. J. (2003). Submission to the Senate Inquiry into the Plastic Bag (Minimisation of Usage) Education Fund Bill 2002 and Plastic Bag Levy (Assessment and Collection) Bill 2002. Queensland: Queensland Parks and Wildlife Service.

Silverman, D. (2001). Interpreting qualitative data: Methods for analysing talk, text and interaction. Sage: London. 
Stevens, E. S. (2002). Green plastics: An introduction to the new science of biodegradable plastics. Princeton University Press: Princeton.

Zero Waste New Zealand Trust (2003). Zero Waste New Zealand: Plastic Shopping Bag Report. Auckland: Zero Waste New Zealand Trust. 